\title{
Simulation of the use of porous pavement and infiltration trench in public spaces supporting mobility
}

\author{
Simulação do uso de pavimento permeável e trincheira de \\ infiltração em espaços públicos de mobilidade
}

\author{
Talita Montagna ${ }^{a}$ \\ Rafaela Vieirab \\ Vander Kaufmann ${ }^{c}$ \\ Adilson Pinheiro $^{\mathrm{d}}$ \\ Gean Paulo Michele \\ ${ }^{a}$ Master in Environmental Engineering, PhD Student, Fundação Universidade Regional de Blumenau, \\ Blumenau, SC, Brazil \\ E-mail: talitamontagna@hotmail.com \\ ${ }^{b}$ PhD in Geography, Professor, Fundação Universidade Regional de Blumenau, SC, Brazil \\ E-mail: arquitetura.rafaela@gmail.com \\ ${ }^{c}$ PhD in Water Resources and Sanitation, Researcher, Fundação Universidade Regional de Blumenau, \\ Blumenau, SC, Brazil \\ E-mail: vanderkaufmann@gmail.com \\ ${ }^{d}$ PhD in Physics and Environmental Chemistry, Professor, Fundação Universidade Regional de \\ Blumenau, Blumenau, SC, Brazil \\ E-mail: pinheiro@furb.br \\ e PhD in Water Resources and Environmental Sanitation, Professor, Universidade Federal do Rio \\ Grande do Sul, Porto Alegre, RS, Brazil \\ E-mail: gean.michel@ufrgs.br \\ doi:10.18472/SustDeb.v12n1.2021.30006
}

ARTICLE - VARIA

\section{ABSTRACT}

The use of sustainable techniques to the basic infrastructure of a city is a way of win back public spaces. This study evaluates the impacts of public spaces supporting mobility. We give focus to areas constructed with porous pavement and integrated with infiltration trenches and hydrological processes. The hydrological simulation was performed with a SWAT model. The hydrographic basin has $54.05 \mathrm{~km}^{2}$ and the area of excess flows' control is $0.66 \mathrm{~km}^{2}$. The peak flow damping was $1.84 \%$, and the surface 
runoff represented $2.82 \%$ of the water depth over the simulated period. We observed a maximum reduction of $7.9 \%$ in the height of the water layer for isolated events. We found positive results in the dampening of the peak flow in the basin exhaust and water flow reduction at the superficial runoff.

Keywords: Urban water management. Flow control at the source. Extreme hydrological events. Hydrological modelling.

\section{RESUMO}

O uso de técnicas sustentáveis na infraestrutura básica de uma cidade é um modo de reconquistar os espaços públicos. O objetivo deste estudo é avaliar os impactos nos processos hidrológicos dos espaços públicos que apoiam a mobilidade se constituídos por pavimento permeável e integrados a trincheiras de infiltração. A simulação hidrológica foi realizada com o modelo Swat. A bacia hidrográfica possui $54,05 \mathrm{~km}^{2}$ e a área com controle dos escoamentos excedentes é de 0,66 km². O amortecimento da vazão de pico foi de 1,84\% e do escoamento superficial em 2,82\% da altura da lâmina-d'água ao longo do período simulado. Para um evento isolado, observou-se uma redução máxima de 7,9\% da altura da lâmina de água. Observaram-se resultados positivos no amortecimento da vazão de pico no exutório da bacia e a redução da lâmina de água do escoamento superficial.

Palavras-chaves: Manejo de águas urbanas. Controle de escoamento na fonte. Eventos hidrológicos extremos. Modelagem hidrológica.

\section{INTRODUCTION}

The urbanization process implies impermeable surfaces expansion, increasing problems related to the drainage of rainwater. The effects of this process are evidenced mainly on water resources. According to Papafotiou and Katsifarakis (2015), many of the impacts of urbanization are negative, such as reducing aquifer recharge and increasing runoff, leading to an increased threat of flooding and flooding. According to Righetto (2009), control measures for urban runoff must have two basic objectives: control of increase in maximum flow and environmental conditions improvement. These objectives should be promoted with non-structural measures of urban planning. These constitute the laws and plans for city planning and serve as a basis for structural measures determination, or the Sustainable Drainage Systems (Suds) of control at the source for rain runoff (BAPTISTA; NASCIMENTO; BARRAUD, 2011). These measures can be inserted in the urban context, in sidewalk areas, and several public spaces.

This conservationist view is necessary to mitigate the negative impact of urbanization on the polluting surface runoff, from an environmental perspective. Sustainable control measures application at the source, such as permeable pavement and infiltration trenches in public areas, needs integration of land-use planning, environmental protection, and transport systems. Correa, Cunha, and Boareto (2010) consider them daily problems for people who move around the cities. The concern with the infrastructure for pedestrian mobility should help the urban drainage system. These can form an efficient practice to mitigate the damage caused by extreme hydrological events. The areas for nonmotorized urban mobility, for example, can be adapted to control measures at the source, such as the permeable pavement and infiltration trenches (BAPTISTA; NASCIMENTO; BARRAUD, 2011).

The study area in this research is the municipality of Blumenau, located in the hydrographic basin of the Itajaí River, in Santa Catarina State. In recent decades, with high frequency, several streets in the municipality of Blumenau are flooded when heavy rains occur, the one that concentrates a large volume of precipitated water during a determined time (PORTO et al, 2012). In January 2018, in the interval of 2 hours, it rained an average accumulation of $85 \mathrm{~mm}$, a height considered high (PARAIZO, 2018). In this event, 417 occurrences recorded by the Civil Defense of Blumenau, among which were situations of landslides, flooding, and request for risk analysis. Several flooding events were identified in the Velha River basin, located in its lower stretch, evidencing the priority of this research on flood 
damage mitigation in this study area. Some Suds techniques are better adequate for urban areas due to the adequacy of the available space. The permeable pavement and the infiltration trench are control techniques at the source that can be easily adapted in urban environments to increase runoff reduction and is the object of study in this research.

We can verify the analysis of impacts from using these techniques is through simulation with hydrological modelling. The hydrological modelling allows the representation of water flow behaviour in the hydrographic basin (PORTO, 1995). It is an adequate tool for performance evaluation of Suds technique, as control techniques at the source (TOMINAGA, 2013). One of the models widely used to simulate water behaviour, with recent research (WANG, 2015; SEO et al., 2017) explored for simulating control techniques at the source in a watershed, is the Soil and Water Assessment Tool (SWAT). SWAT adopted in this research serves for its graphical interface associated with the GIS locating the control structures at the source for its simulation. Besides, it is useful for analyzing the influence of these structures at the hydrographic basin exhortation. Given this context, we assess the impact on the surface runoff of public spaces that support non-motorized mobility in the lower stretch of the Velha River basin in Blumenau-SC. We analyse if they consist of permeable pavement and evaluate a second scenario with the permeable pavement distributed in lanes and with an infiltration trench replacing the gutters.

\section{MATERIALS AND METHODS}

\subsection{DESCRIPTION OF THE STUDY AREA}

The study area comprises a hydrographic basin in the municipality of Blumenau / SC, frequently affected by floods and floods. The hydrographic basin of the Velha River is located to the northeast of the state of Santa Catarina with coordinates of latitude 260 $55^{\prime} 20^{\prime \prime}$ S and longitude 4903' $12^{\prime \prime}$ W north direction and latitude 260 54' 00,68" S and longitude 4905'47, 00" W south direction (Figure 1).

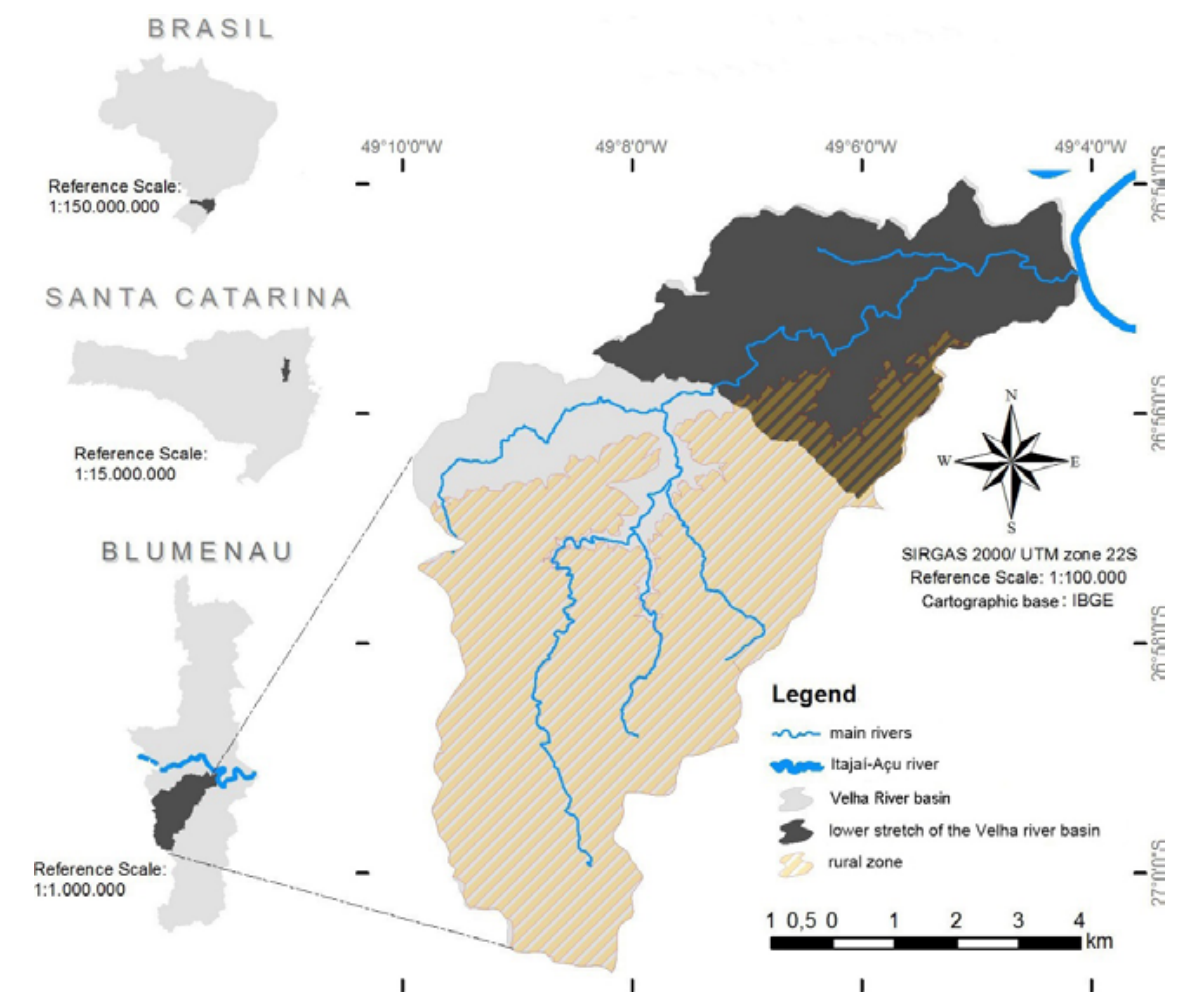

Figure 1 | Location map of the Velha River hydrographic basin: lower stretch of the basin, rural area, and watercourse. 
This hydrographic basin has an area of $54.05 \mathrm{~km}^{2}$. Most of the hydrographic basin is a rural area, equivalent to $60.8 \%$, mostly covered by remaining vegetation. The urban area comprises $39.2 \%$ of the total area, with residential, commercial, leisure, and industrial areas, among other uses.

The simulation with the SWAT model involves the entire extension of the Velha River basin. However, to analyse impacts from the implantation of permeable pavement and the infiltration trench, we quantify the areas for Suds application, according to Montagna and Vieira (2019). We simply consider the lower stretch of the hydrographic basin of the Velha River (Figure 1). It is the most urbanized area of the hydrographic basin.

With an area of $17.14 \mathrm{~km}^{2}$, covering approximately $83.5 \%$ of the urban area, it has arterial roads and collectors that serve as access to the other important neighbourhoods of the city and that frequently experience flooding threats, causing mobility disorders, among other losses.

A portion of the buildings in the lower part of the Velha River hydrographic basin is below $10 \mathrm{~m}$ flood level. This is the reference value of the Blumenau fluviometric station on the Itajaí-Açu river, to which the Velha stream is affluent. The alteration of LC 751/2010, which provides for the zoning, use, and occupation code of the land in Blumenau, by LC 1.039 / 2016 (BLUMENAU, 2016), restricts residential use below $12 \mathrm{~m}$ flood level and the other uses below of the $10 \mathrm{~m}$ flood level due to the frequency of flooding in the Itajaí River basin. However, some buildings on stilts, a recreation area that does not interfere with water flow, an underground parking lot, and infrastructure installation for the public road system may be allowed in these places. According to Schult and Pinheiro (2003), for Blumenau, the $10 \mathrm{~m}$ flood level presents a return time of 4 years.

\subsection{DATA COLLECTION}

This survey comprises area quantification for applying permeable pavement and infiltration trenches in the lower stretch of the Velha River basin. The use of permeable pavement was determined in two different situations. The first scenario relies on the application of permeable pavement only in public areas of non-motorized mobility (sidewalks, cycle paths, and paved park areas). According to Montagna and Vieira (2019), collection procedures served to tabulate data on the characteristics of extension and composition of the covering of public areas that support existing non-motorized mobility based on field observations on arterial and collecting roads.

The second scenario, other than the public areas of non-motorized mobility already quantified, it includes bearing bands for permeable pavement and gutters for an infiltration trench (Figure 2). The use of an infiltration trench was indicated instead of gutters along the lanes of arterial roads, collectors, and some places. 


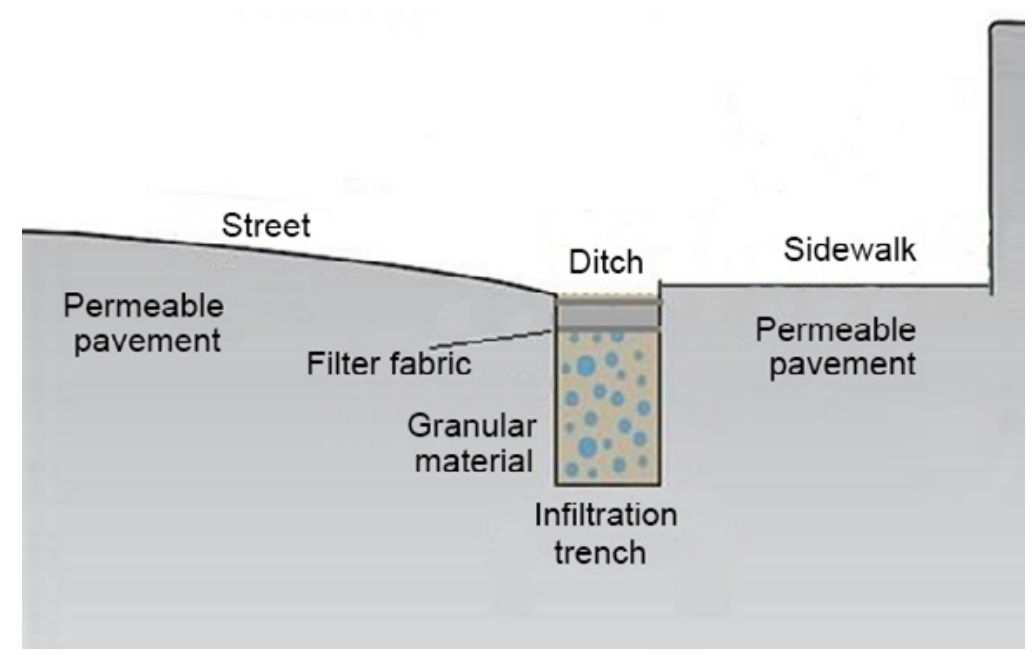

Figure 2 | Profile representation of the proposed adaptation of drains, sidewalks, and draining lanes.

$$
\text { Source: Adapted from Santos (2009) }
$$

These areas were quantified from the existing and projected road map of the municipality of Blumenau, available in dwg. format by the department of management of cartography and multipurpose registration of the City of Blumenau, selecting these areas in arterial routes, collectors, and some places. The design was carried out by creating polygons that represent these areas for the implementation of Suds.

Emphasizing that the NBR 16.416 (ABNT, 2015) of permeable concrete pavement limits the use of permeable pavement in light traffic lanes. Considering these lanes of lanes helps to obtain a larger simulation area. The infiltration trenches have a standard width of $30 \mathrm{~cm}$, given the width observed along the roads in most stretches and the extension of the blocks.

The input data for the creation of the SWAT database includes tabular and spatial representation data. Tabular data comprises precipitation data as well as climatic data. Spatial data include the Digital Terrain Model (MDT), a tif image file with the basin to be limited, a map containing the hydrography, the land use map, and the soil map of the watershed under study.

The precipitation data used were obtained from the hydro web of the National Water Agency (ANA, 2018) of the station installed on the Adolfo Konder bridge, in Blumenau / SC, code 2649122, covering the period from $01 / 01 / 2012$ to $12 / 31 / 2017$. The precipitation time series was inserted with an interval of 30 minutes to perform the sub-daily simulation, using the Green \& Ampt infiltration method. With this method, as the water infiltrates the soil during the infiltration process, we assume there is a saturation in the region above the wetting front. The model calculates the infiltration assuming the surplus of water on the surface throughout the precipitation event (GREEN; AMPT, 1911).

The climatic data (temperature, solar radiation, wind speed, and relative humidity) were consisted of and provided by Knaesel (2019). We extracted the data from the National Institute of Meteorology (INMET) website. We consider stations located in the municipalities of Indaial and Ituporanga / SC, from $01 / 2012$ to $12 / 2017$, which comprises the same period as the precipitation data. We selected meteorological stations neighbouring the basin that presented similar topographic and climatic characteristics, as they present a better quality of the monitored data. The climatological data required by the SWAT model daily, even for sub-daily simulations.

For the spatial representation, the Digital Terrain Model (MDT) of the area is from the year 2010, obtained from the website of the Geographic Information System of Santa Catarina (SIGSC), on the scale of 1:10,000 
with a pixel resolution of $1 \mathrm{~m}$, inserted already with the clipping of the study area. We associated, with this project, the RGB orthophotos in .tif format obtained on the SIGSC website, with a resolution of 0.39 $\mathrm{m}$. Another spatial data is the hydrography of the basin, also from SIGSC, on a scale of 1: 10,000.

For soil data, the map used comes from the IBGE database prepared by the Brazilian Agricultural Research Corporation (EMBRAPA) in 2001. This map is on a 1: 250,000 scale. Given the need of changing land use and soil type for simulations with the insertion of Suds, we created two types of land use and two of soil in the SWAT database. Land use and soil type representing the permeable pavement are named Pper. For land use and soil type that represent the infiltration trenches, it was called Tcha.

The permeable pavement structure and the infiltration trench contain a reservoir base layer, composed of gravel with a certain depth. In this way, the type of soil will receive changes in its characteristics to represent these gravel structures to replace the local soil.

Thus, the type of soil created initially received the same values for the parameters that represent the characteristics of the current one in which, in this case, we find Red Yellow Clay soils. For the new classes of land use, parameters values (Table 1) representing use characteristics, came from Liu et al. (2017) article on paved roads. In this research, parameters' values represent the characteristics of current uses and permuted to permeable pavement and infiltration trench with scenarios simulation.

Table 1 | Parameters adopted for Pper and Tcha land-use class.

\begin{tabular}{|l|l|c|}
\hline Variable & Definition & Data \\
\hline URBNAME & 4-character code for urban land type & PPER/CHA \\
\hline URBFLNM & Full name or description of urban land type & $\begin{array}{c}\text { Porous pavement/ } \\
\text { Infiltration trench }\end{array}$ \\
\hline FIMP & Fraction total impervious area in urban land type & 0.6 \\
\hline FCIMP & Fraction directly connected impervious area in urban land type & 0.44 \\
\hline CURBDEN & Curb length density in urban land type (km/ha) & 0.05 \\
\hline URBCOEF & Wash-off coefficient for removal of constituents from impervious area (mm-1) & 0.18 \\
\hline DIRTMX & Maximum solids allowed to accumulate in the impermeable area & 170 \\
\hline THALF & Number of days to accumulate half of the allowed solids (days) & 3.9 \\
\hline TNCONC & $\begin{array}{l}\text { Concentration of total nitrogen in suspended solid load from impervious areas } \\
\text { (mg N/kg sediment) }\end{array}$ & 480 \\
\hline TPCONC & $\begin{array}{l}\text { Concentration of total phosphorus in suspended solid load from impervious } \\
\text { areas (mg P/kg sediment) }\end{array}$ & 212 \\
\hline TN03CONC & NO3-N/kg sediment) & 63 \\
\hline OV_N & Manning's roughness for pervious fraction & 0.1 \\
\hline CN2A & Curve number for hydro group A for pervious fraction & 31 \\
\hline CN2B & Curve number for hydro group B for pervious fraction & 59 \\
\hline CN2C & Curve number for hydro group C for pervious fraction & 72 \\
\hline CN2D & Curve number for hydro group D for pervious fraction & 79 \\
\hline URBCN2 & Curve number for impervious fraction & 89 \\
\hline
\end{tabular}

Source: Adapted Liu et al. (2017)

To replace the current pavement parameters with permeable pavement characteristics in these areas, we changed two maps. The public areas of non-motorized mobility, identified by Montagna and Vieira (2019), were represented on the soil and land use maps. In this way, the polygons created in Autocad (Figure 3), representing these areas, have replaced the original layer. 

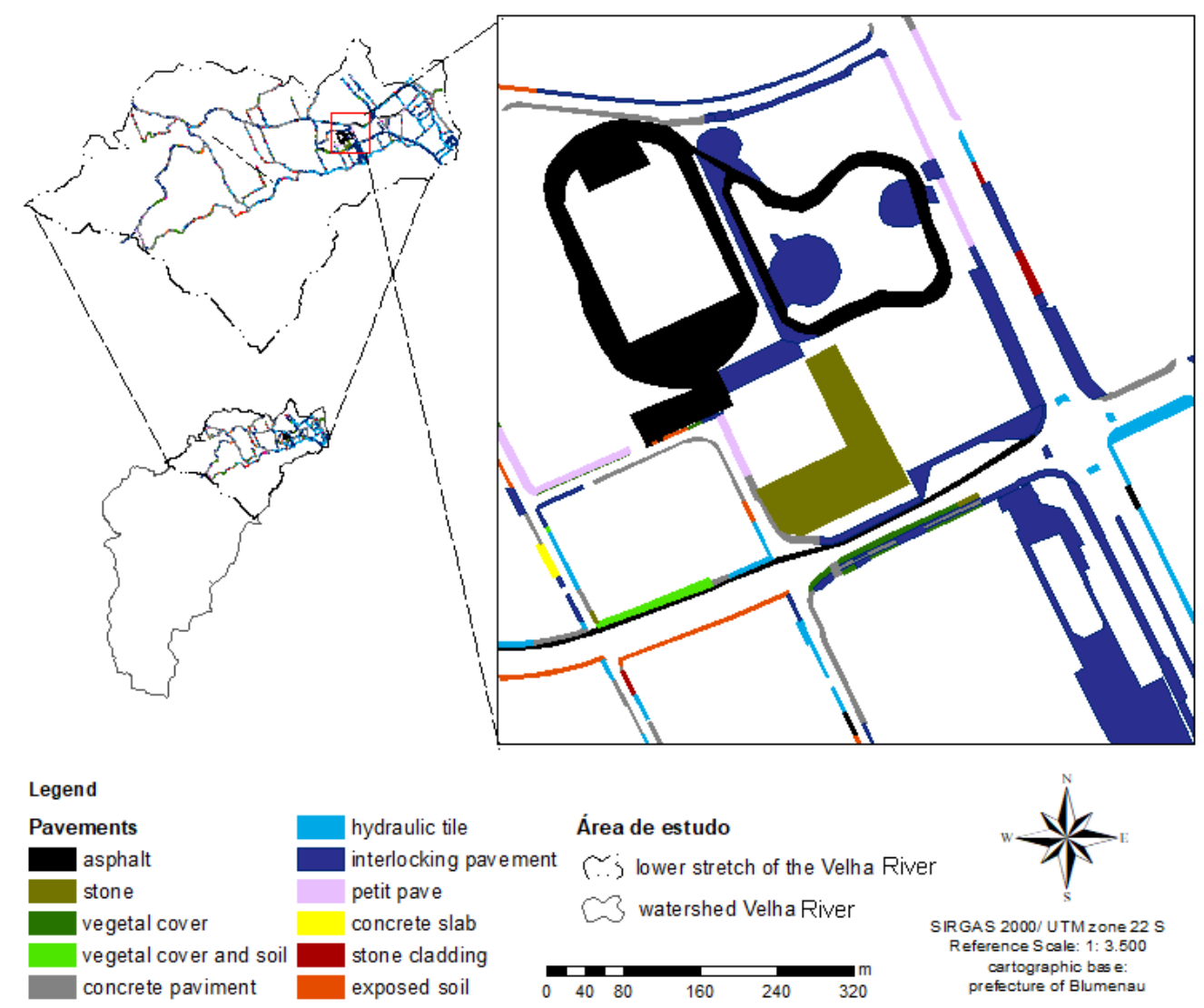

Figure 3 | Map of public areas of non-motorized mobility quantified in the lower stretch of the Velha River basin and the types of coverings identified.

Source: Montagna and Vieira (2019)

The gutter areas and quantified rolling lanes were also represented on the soil and land use maps (Figure 4).

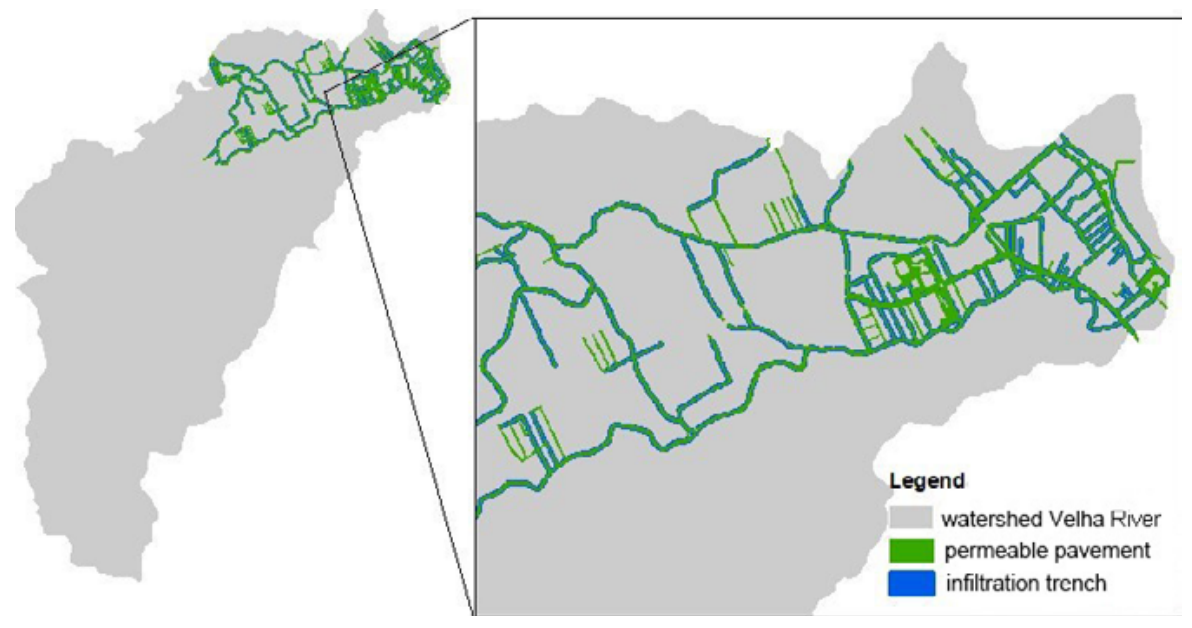

Figure 4 | Representation of areas with proposed incorporation of Suds (permeable pavement and infiltration trench) in public areas of non-motorized mobility and rolling lanes of motorized mobility routes 
Due to the absence of monitoring data from the Velha River, it was not possible to generate the key curve of the fluviometric simulation section. The values of the parameters used for calibration in this study were equal to those determined by Venzon (2018). In his study, he evaluated a hydrographic basin of similar proportion and characteristics.

We compared the results obtained, through the simulation of the calibrated basin with Venzon's parameters, with the quota data observed in the Velha River. The Velha River basin has quota data records valid from $01 / 01 / 2012$ to $12 / 31 / 2013$. We opted for a period of two years preceding the beginning of the evaluated period, January 2010 to December 2011, to warm up the model, that is, model stability during its interactive processes to obtain the results. The uncertainties in the initial conditions can be minimized using a period of heating of the model that allows reducing the eventual errors existing in the initial conditions (WAGENER; WHEATER; GUPTA, 2004).

The validation of the data generated after these adjustments to the model parameters corresponds to the last step of verifying a hydrological model. Briefly, the validation consists of executing the model with the adjustments of the parameters determined in the calibration for a period of real data different from the one used in the calibration (ARNOLD et al., 2012). The simulation was carried out from January 2012 to December 2012 for calibration and from January 2013 to December 2013 for validation. The results are compared visually and using the coefficient of determination $\left(R^{2}\right)$ to assess the performance of the model. The $R^{2}$ represents the linear association between the measured and simulated data and ranges from 0 to 1 .

\subsection{REPRESENTATION OF THE PERMEABLE FLOOR AND INFILTRATION TRACK}

The height dimensioning of the reservoir layer of the permeable pavement for the study area was performed by Camargo de Souza (2018), obtaining heights from 2.76 to $216.8 \mathrm{~m}$. Physically, a $216.8 \mathrm{~m}$ reservoir is not coherent since there is no soil with such layer depth. Thus, we decided to simulate four different heights, being $0.5,1,1.5$, and $3 \mathrm{~m}$. The latter was determined to be the maximum depth that the local soil reaches the rock.

For the representation of the permeable pavement and the infiltration trench in the model, it is necessary to understand the entire structure that comprises them. Thus, we incorporated the permeable pavement and the infiltration trench according to Figures 5 and 6 , respectively. The surface is defined by the land use parameters (Urban), and then the Suds structure layers are incorporated into the existing soil layers (User soil).

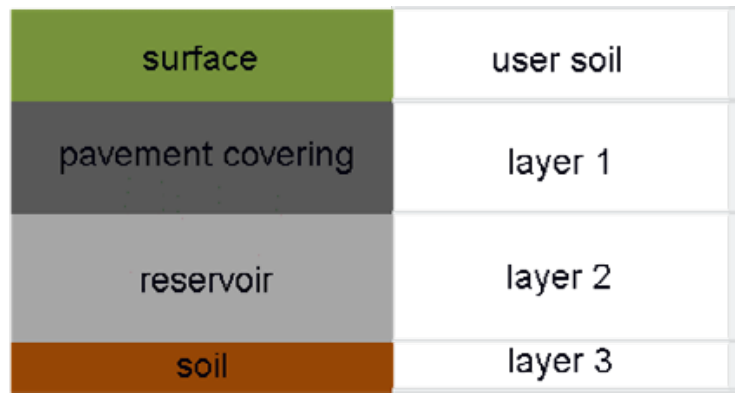

Figure 5 | Composition of the permeable pavement structure layers represented in the SWAT for simulation. 


\begin{tabular}{|c|c|}
\hline surface & user soil \\
\hline reservoir & layer 1 \\
\hline soil & layer 2 \\
\hline
\end{tabular}

Figure 6 | Composition of the layers of the infiltration trench structure represented in the SWAT for simulation.

Source: Montagna (2019).

\section{Land use parameters (Urban)}

To represent the use of permeable pavement and infiltration trench, we had to identify and change the parameters that characterize this technique. According to Wang (2015), the SWAT parameters that represent the use of permeable concrete covering are the flow coefficient (FIMP), the number curve (CN2), and the surface roughness of the coefficients (OV_N). These parameters characterize the surface in use. In this way, the same parameters are modified for the PPER and TCHA uses in Urban (Chart 2) of the SWAT model.

Table 2 | Land use parameters

\begin{tabular}{|l|l|}
\hline Parameters & Definition \\
\hline FIMP & $\begin{array}{l}\text { corresponds to the runoff coefficient, representing the runoff coefficient of the } \\
\text { permeable concrete and that of the gravel in the trench. }\end{array}$ \\
\hline CN2 & $\begin{array}{l}\text { represents the numerical curve for a humidity condition II. The value of the CN2 } \\
\text { parameter corresponding to that of the forests will be used, as it is the condition } \\
\text { closest to the natural. }\end{array}$ \\
\hline OV_N & $\begin{array}{l}\text { represents the roughness of the materials, being presented by the SWAT manual } \\
\text { as the value of " } n \text { " manning for the surface runoff. }\end{array}$ \\
\hline
\end{tabular}

Source: adapted from Arnold et al (2012)

Wang's methodology (2015) that used the SWAT model for the Suds simulation considered only the change in land use properties. Thus, to represent the complete structure of the permeable pavement and the infiltration trench, we took the base layers (reservoir function) of the Suds in the soil parameters (User soils).

\section{Soil parameters (User soils)}

The structure of permeable pavement and infiltration trench is installed at a certain depth, requiring the removal of the earth. In this way, soil parameters need to be changed to represent this new structure in the hydrological model.

The current soil has three layers of soil (NLAYERS). The same soil presents variations between the layers. To support the coating, reservoir, and soil layers, we had to increase the number of layers to 4 (four). We also changed the soil hydrological group (HYDGRP), the heights of soil layers (SOL_Z), the density of wet volume (SOL_BD), water capacity (SOL_AWC), hydrological conductivity at saturation (SOL_K), silt content (SILT), sand content (SAND) and rock content (ROCK). In this way, identified soil parameters of the SWAT model are modified, and the values are determined according to the material properties. 


\section{RESULTS AND DISCUSSION}

\subsection{CALIBRATION AND VALIDATION OF MODEL PARAMETERS}

The flow data for the Velha River came from Venzon's calibration. The relationship between the flow generated and quotas observed in the basin is shown in Figure 7. The relationship between the quotas observed for the period 2012 to 2013 is noted with the hydrograph generated. When compared with series of measured dimensions, series of the simulated flows show adequate alignment in time variations and more dispersion during higher flow events.

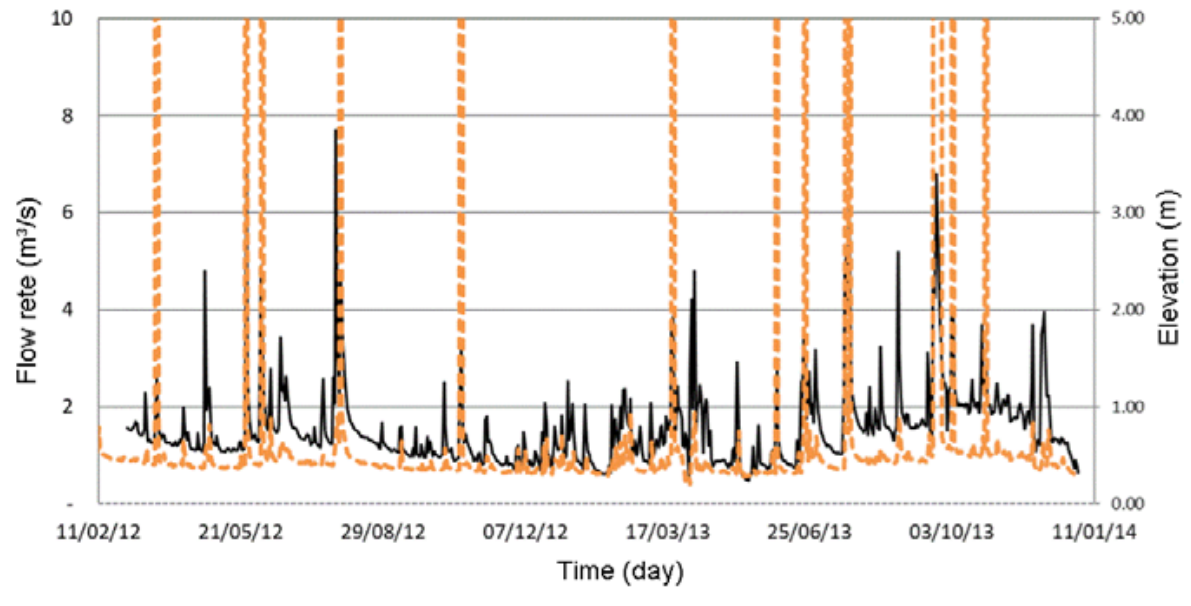

- Calibrated flow $\quad---$ Elevation

Figure 7 | Relation of the flow generated by the calibrated model with the dimensions measured in the Velha River Source: Montagna (2019).

The verification of the model's performance by the coefficient of determination $\mathrm{R}^{2}$ showed an acceptable correlation $\left(R^{2}=0.51\right)$ between the simulated flow and the quotas observed by the monitoring (Figure 8). Thus, to adjust the studied basin with data from a basin with similar characteristics, we considered this model to apply it for simulations in the study area.

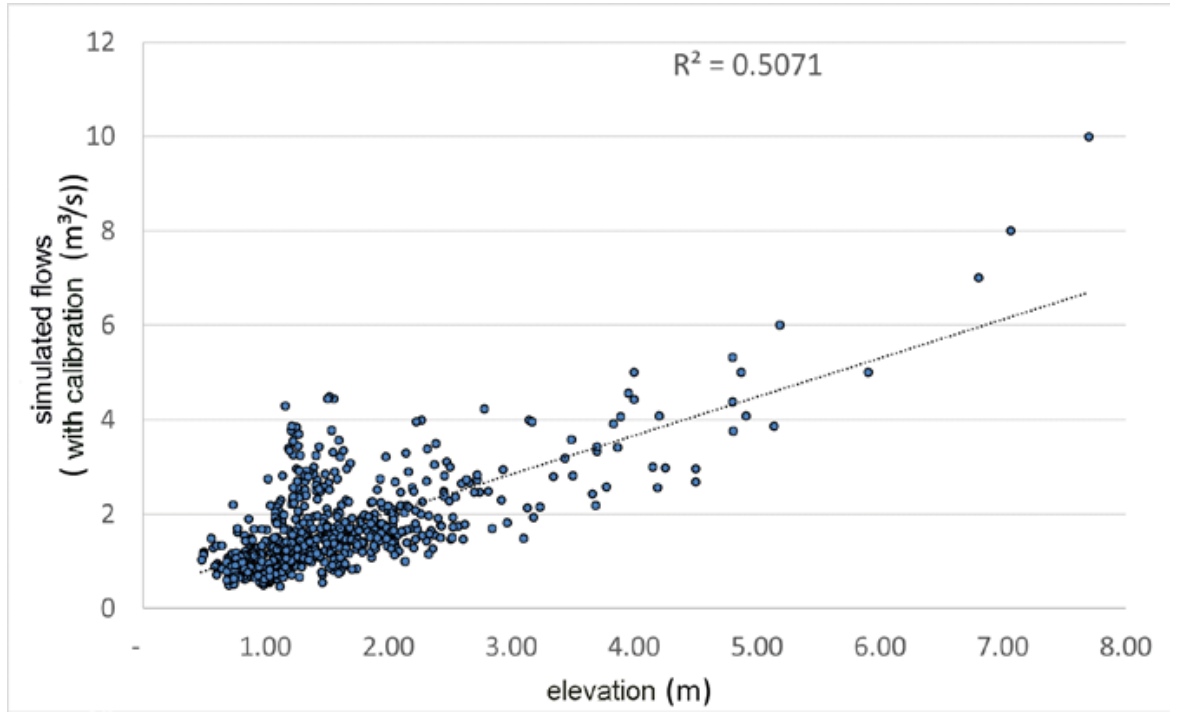

Figure 8 | Correlation between the simulated flow and the quotas observed by the monitoring. 


\subsection{EXUTORY FLOW}

The proposal to verify the impact of replacing the current pavement in public areas of non-motorized mobility with permeable pavement, scenario 1 , led us to a permeable pavement application area of $0.2152 \mathrm{~km}^{2}$, which represents $1.26 \%$ of the stretch area bottom of the Velha River basin, which has an area of $17.14 \mathrm{~km}^{2}$.

For the second scenario, which uses two Suds techniques, permeable pavement and infiltration trench, where the permeable pavement was considered in addition to the public areas of non-motorized mobility already quantified, the road lanes were also quantified. We obtained $0.42 \mathrm{~km}^{2}$ for the rolling lanes of arterial roads, collectors and some locations. This shows a $2.48 \%$ portion of the lower stretch of the Velha River basin.

Finally, the total quantified area of gutters, to be replaced by an infiltration trench, was $0.02 \mathrm{~km}^{2}$ which represents a percentage of $0.12 \%$ of the total area of the lower stretch of the Velha River. Thus, for the second scenario, we obtained an area of $0.64 \mathrm{~km}^{2}$ for permeable pavement application (public areas of non-motorized mobility and rolling lanes) and $0.02 \mathrm{~km}^{2}$ for the implantation of infiltration trenches (gutter).

Concerning the lower section in which these areas were quantified, they are equivalent to a percentage of $3.85 \%$. These areas were represented in the land use and soil type maps for later use in the SWAT hydrological model. Quantifications proportions for these areas are in Table 3. We outlined the proportions of their contrition area (sub-basins) by the expressed topography.

Table 3 | Proportion of non-motorized mobility area by sub-basin

\begin{tabular}{|c|c|c|c|c|}
\cline { 3 - 5 } \multicolumn{2}{c|}{} & Scene 1 & \multicolumn{2}{c|}{ Scene 2 } \\
\hline Sub-basin & $\begin{array}{c}\text { Sub-basin area } \\
\left(\mathbf{k m}^{2}\right)\end{array}$ & $\begin{array}{c}\text { Porous pavement } \\
\text { area (\%) }\end{array}$ & $\begin{array}{c}\text { Porous pavement } \\
\text { area (\%) }\end{array}$ & $\begin{array}{c}\text { Infiltration trench } \\
\text { area }\end{array}$ \\
\hline 1 & 2.57 & 1.041 & 2.93 & 0.11 \\
\hline 2 & 0.001 & 6.232 & 11.92 & 0.1 \\
\hline 3 & 3.359 & 3.867 & 10.21 & 0.33 \\
\hline 4 & 2.009 & 1.022 & 2.74 & 0.1 \\
\hline 5 & 0.107 & 0.527 & 1.76 & 0.07 \\
\hline 6 & 1.153 & 0.072 & 0.31 & 0.01 \\
\hline 7 & 4.582 & 0.072 & 3.19 & 0.14 \\
\hline 8 & 1.381 & 0 & 0 & 0 \\
\hline 9 & 1.239 & 0 & 0 & 0.03 \\
\hline 10 & 1.324 & 0.247 & 0.79 & \\
\hline Total & 17.14 & \multicolumn{3}{c}{}
\end{tabular}

Source: Montagna (2019).

The hydrological response units, generated from the combination of land use, soil type, and slope, generated 440 HRUs for scenario 1 and 477 HRUs for scenario 2. There are 37 more HRUs compared to scenario 1 , due to the inclusion of land use and soil for infiltration trench. The topography of the study area presented 26 sub-basins, as shown in Figure 9. 


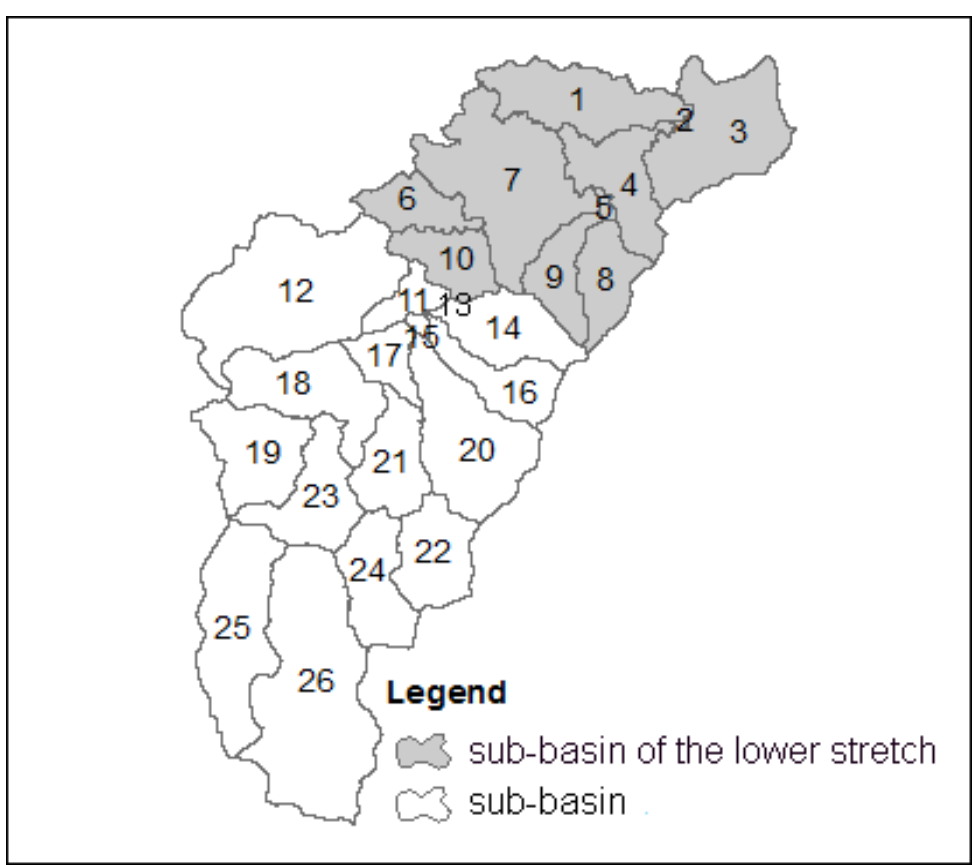

Figure 9 | Representation of the 26 sub-basins delimited by SWAT processing in the study area, with emphasis on the sub-basins of the lower stretch of the hydrographic basin of the Velha River.

Source: Montagna (2019).

Flow rates in the exutory (exit section), for both scenarios, showed a slight decrease for the different depths. We noticed the peak flow rates of our studied period concentrate in less than $10 \%$ of the time (Figures 10 and 11), exceeding a flow of $4 \mathrm{~m}^{3} / \mathrm{s}$. It is precisely at this peak flow rate that Suds techniques can mitigate flow rates. These techniques allow most of the water to seep into soil layers and keep the flow somehow higher over time, due to water flow from maintaining natural soil conditions.

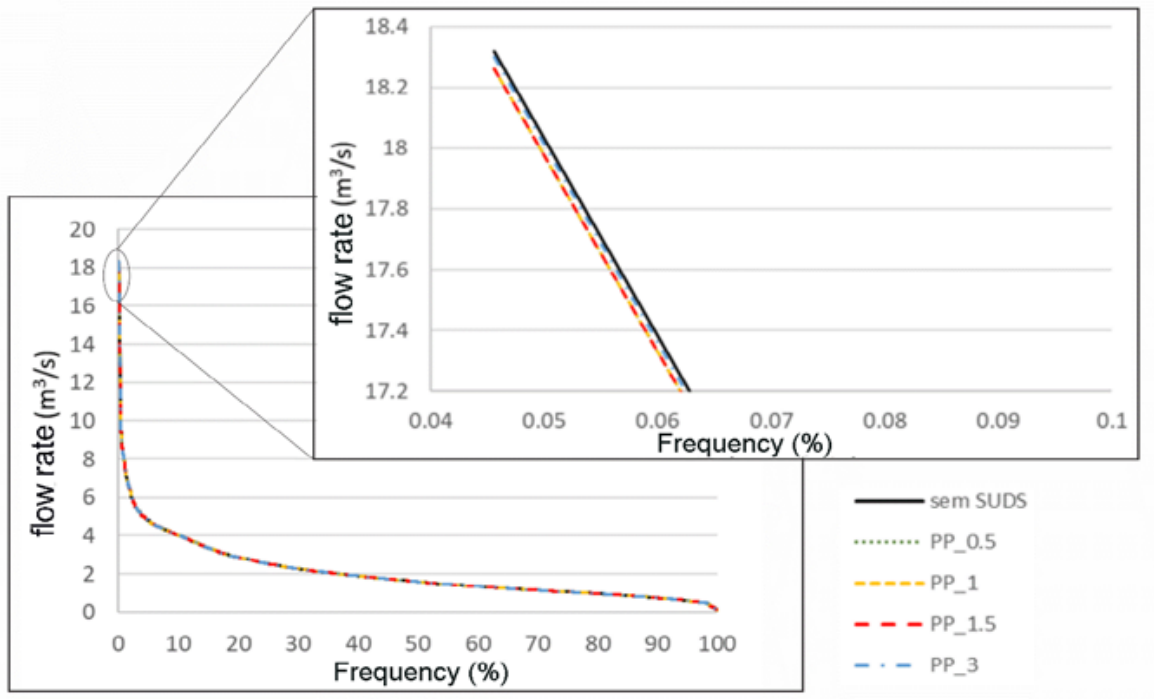

Figure 10 - Permanence curve of scenario 1 with the frequency of the simulated flows, for each defined depth, of the permeable pavement structure. 


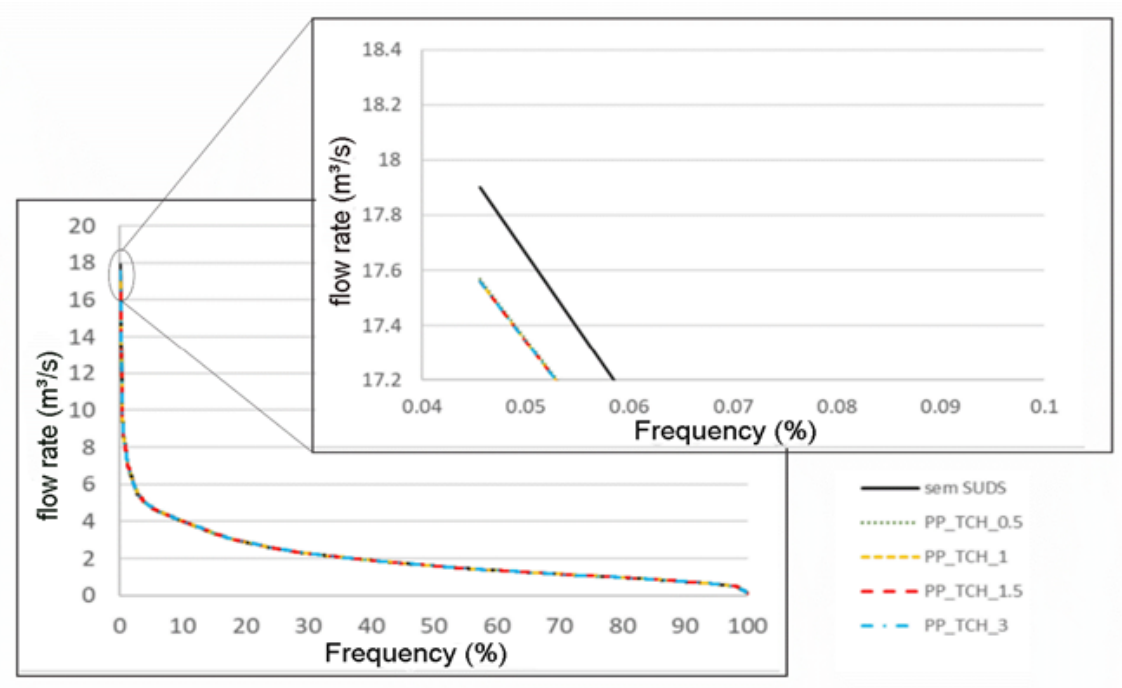

Figure 11 | Permanence curve of scenario 2 with the frequency of the simulated flows, for each defined depth, of the permeable pavement structure and infiltration trench.

Legend: PP_TCH represents permeable pavement and infiltration trench, followed by the depth of the structure.

Source: Montagna (2019)

Observing the permanence curve of the whole series analyzed for both scenarios, we can not easily visualize the effects on flows due to trivial reduction values obtained. However, when evidencing the peak flows, highlighted in Figures 10 and 11, with flows greater than $17.2 \mathrm{~m}^{3} / \mathrm{s}$, a reduction of $0.33 \%$ of the highest peak flow is observed for scenario 1 and scenario 2, a 1.84\% reduction in the highest peak flow.

Nunes (2018), through modelling with the SWMM, evaluated the implementation of green roofs and permeable pavements in $50 \%$ of the total area of the basin, which generated reductions in peak flows of $6.8 \%$ for the return time of 10 years and $5.9 \%$ for the 50 -year payback time. Several factors influence the difference in flow rates obtained, including the proportion of Suds considered in the studies.

In the first scenario, the highest peak flow reduction was $60 \mathrm{l} / \mathrm{s}$ for a $0.5 \mathrm{~m}$ depth. Even if the area considered for simulation of the permeable pavement represents $0.40 \%$ of the total area of the 54.05 $\mathrm{km}^{2}$ basin, we still noticed influence on the reduction of peak flows. With the increase in Suds application in scenario 2, we obtained a maximum reduction of $760 \mathrm{l} / \mathrm{s}$ for the depth of the structures of $1 \mathrm{~m}$. In this scenario, an application of $0.66 \mathrm{~km}^{2}$ of Suds in the experimental basin, $214 \%$ more than in scenario 1 , we observe a proportional increase in flow reductions. This proves the importance of Suds distribution in larger areas, including use within the lots to obtain a greater effect and the implementation of more green spaces for public use such as squares and parks.

Note that in both scenarios, along with the lowest flows, that is, more frequently, the simulated flow is higher than the flows of the current scenario. Due to the possibility of greater water infiltration in the soil, this water takes longer to reach the water body and will keep it fed with a higher flow for a longer time. Due to the low values obtained, we decided to numerically demonstrate, in Table 1, the results obtained from the outflow, where it is notorious, close values at different depths. Results for flow rates up to $1 \%$ are shown. 
Table 4 | Outflow flows with a frequency of up to $1 \%$

\begin{tabular}{|c|c|c|c|c|c|c|c|c|c|}
\hline \multicolumn{10}{|c|}{ Output flow $\left(\mathrm{m}^{3} / \mathrm{s}\right)$} \\
\hline \multirow{2}{*}{$\begin{array}{c}\text { Frequency } \\
(\%)\end{array}$} & \multirow{2}{*}{\begin{tabular}{|c|} 
Initial \\
W/O PP \\
\end{tabular}} & \multicolumn{4}{|c|}{ Scene 1} & \multicolumn{4}{|c|}{ Scene 2} \\
\hline & & PP $0.5 \mathrm{~m}$ & PP $1 \mathrm{~m}$ & PP_1.5m & PP $3 \mathrm{~m}$ & PP TCH $0.5 \mathrm{~m}$ & PP TCH $1 \mathrm{~m}$ & PP_TCH $1.5 \mathrm{~m}$ & PP TCH $3 \mathrm{~m}$ \\
\hline 0.05 & 18.320 & 18.260 & 18.263 & 18.264 & 18.300 & \begin{tabular}{|l|}
17.570 \\
\end{tabular} & 17.560 & 17.566 & 17.567 \\
\hline 0.09 & 15.350 & 15.310 & 15.311 & 15.315 & 15.320 & 15.311 & 15.313 & 15.314 & 15.318 \\
\hline 0.14 & 15.210 & 15.192 & 15.190 & 15.191 & 15.210 & 15.170 & 15.161 & 15.162 & 15.166 \\
\hline 0.18 & 14.550 & 14.510 & 14.512 & 14.518 & 14.520 & 14.015 & 14.018 & 14.019 & 14.019 \\
\hline 0.23 & 13.870 & 13.800 & 13.801 & 13.805 & 13.810 & 13.530 & 13.530 & 13.530 & 13.530 \\
\hline 0.27 & 11.340 & 11.340 & 11.340 & 11.340 & 11.340 & 11.220 & 11.210 & 11.210 & 11.210 \\
\hline 0.32 & 11.180 & 11.170 & 11.175 & 11.172 & 11.180 & 11.030 & 11.030 & 11.030 & 11.030 \\
\hline 0.36 & 10.590 & 10.600 & 10.600 & 10.600 & 10.610 & 10.440 & 10.440 & 10.440 & 10.440 \\
\hline 0.41 & 9.378 & 9.387 & 9.387 & 9.387 & 9.388 & 9.452 & 9.449 & 9.449 & 9.449 \\
\hline 0.46 & 9.374 & 9.382 & 9.381 & 9.381 & 9.381 & 9.411 & 9.408 & 9.408 & 9.405 \\
\hline 0.50 & 8.685 & 8.686 & 8.687 & 8.687 & 8.686 & 8.755 & 8.753 & 8.752 & 8.753 \\
\hline 0.55 & 8.677 & 8.681 & 8.681 & 8.681 & 8.681 & 8.719 & 8.720 & 8.720 & 8.720 \\
\hline 0.59 & 8.618 & 8.587 & 8.587 & 8.586 & 8.593 & 8.597 & 8.595 & 8.594 & 8.592 \\
\hline 0.64 & 8.568 & 8.576 & 8.575 & 8.575 & 8.574 & 8.374 & 8.374 & 8.374 & 8.374 \\
\hline 0.68 & 8.417 & 8.390 & 8.390 & 8.390 & 8.389 & 8.283 & 8.281 & 8.281 & 8.278 \\
\hline 0.73 & 8.303 & 8.288 & 8.288 & 8.288 & 8.292 & 8.123 & 8.122 & 8.122 & 8.121 \\
\hline 0.78 & 8.238 & 8.242 & 8.241 & 8.241 & 8.242 & 8.121 & 8.121 & 8.121 & 8.121 \\
\hline 0.82 & 8.089 & 8.075 & 8.075 & 8.075 & 8.077 & 7.981 & 7.983 & 7.983 & 7.985 \\
\hline 0.87 & 8.007 & 8.001 & 8.001 & 8.001 & 8.004 & 7.932 & 7.930 & 7.930 & 7.930 \\
\hline 0.91 & 7.969 & 7.973 & 7.973 & 7.973 & 7.973 & 7.841 & 7.841 & 7.841 & 7.841 \\
\hline 0.96 & 7.810 & 7.808 & 7.808 & 7.808 & 7.813 & 7.823 & 7.823 & 7.823 & 7.823 \\
\hline 1.00 & 7.726 & 7.734 & 7.733 & 7.733 & 7.733 & 7.759 & 7.757 & 7.757 & 7.755 \\
\hline
\end{tabular}

Legend: PP represents permeable pavement in the first scenario, PP_TCH represents permeable pavement and infiltration trench in the second scenario.

Source: Montagna (2019)

\subsection{SURFACE FLOW}

The permeable pavement and the infiltration trench are infiltration techniques that aim to reduce runoff. Concerning this function, the Suds proved to be active. Runoff data are expressed daily and by the sub-basin.

In scenario 1 , the sub-basins with the largest proportions of permeable pavement are sub-basins number 2 and 3 . They present an area of $6.23 \%$ and 3.87\%, respectively permeable pavement application in public areas of non-motorized mobility. In scenario 2, the sub-basin with the largest area with permeable pavement and infiltration trenches is number 3 , which has an area of $10.21 \%$ permeable pavement and $0.33 \%$ infiltration trench. These sub-basins were therefore the ones that had the greatest impacts.

As expected, given the draining function of permeable pavement (PP), the height of the runoff was also reduced. In view of the sub-basin with the largest Suds application area, sub-basin 3, the total runoff generated in the simulated period, in scenario 1 , showed a reduction of $0.88 \%$ (PP_0.5m), $0.87 \%$ (PP_1m), 0.86\% (1.5m) and 0.78\% (PP_3m) (Figure 12). 


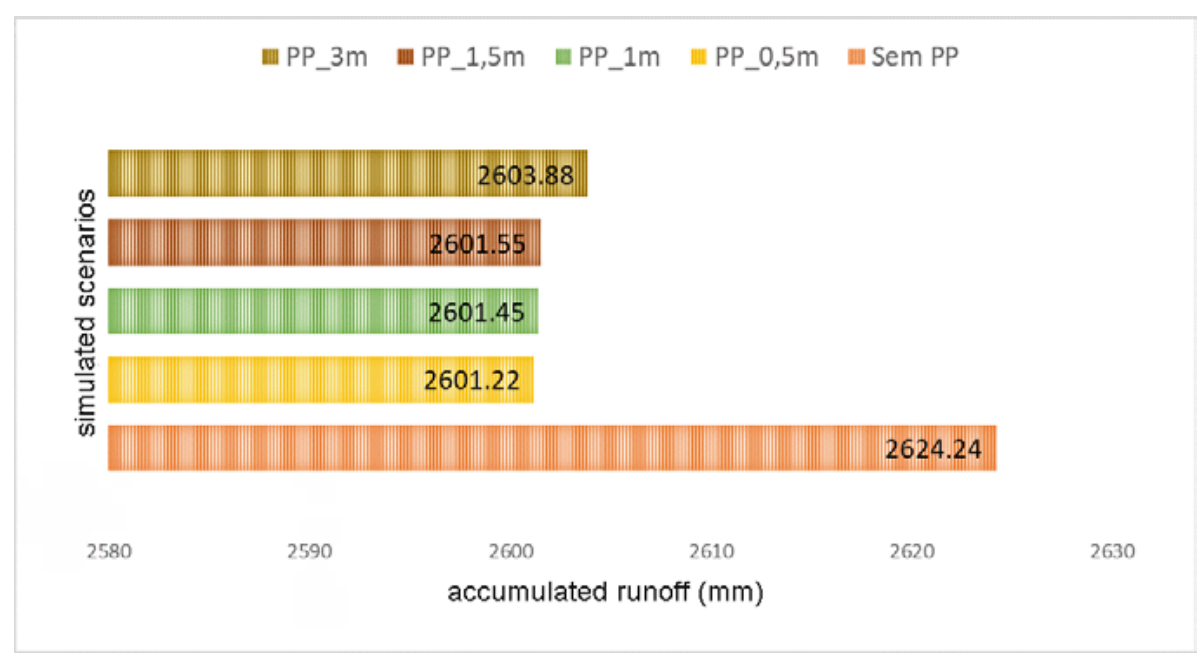

Figure 12 | Bar graph with the amount of accumulated runoff in the simulation of the permeable pavement

Source: Montagna (2019).

Thus, analyzing the runoff of the sub-basin with the largest permeable pavement area considered, a maximum reduction of $0.88 \%$ in the height of the runoff over the analyzed period is identified for the structure depth of $0.5 \mathrm{~m}$. For scenario 2, sub-basin 3 also had a larger area of application of the Suds. The total runoff generated in the simulated period decreased by $2.82 \%$ (PP_TCHA_0.5m), 2.61\% (PP_TCHA_1m), 2.57\% (PP_TCHA_1.5m), and 2.25\% (PP_TCHA_3m) (Figure 13).

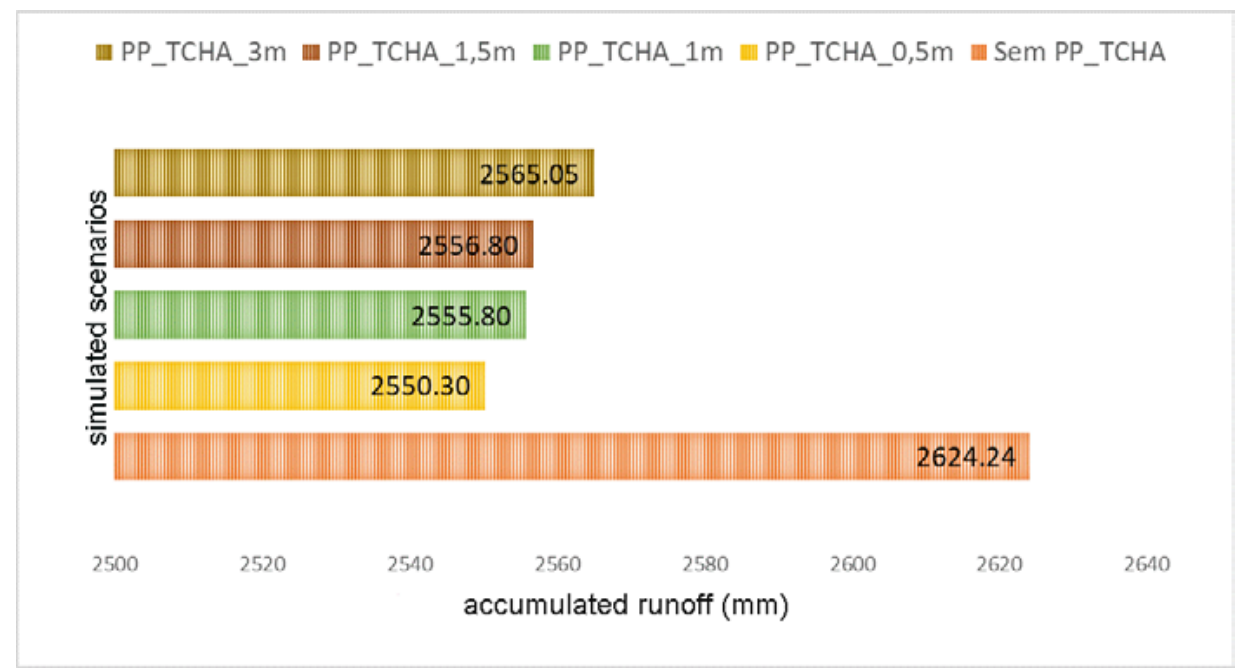

Figure 13 | Bar graph with the amount of accumulated runoff in the simulation of permeable pavement and infiltration trench

Source: Montagna (2019)

The fact that the structure with the lowest depth generates the greatest reduction in runoff may be linked to a greater amount and porosity in soil, just below the permeable pavement reservoir structure. When we observed an isolated event of higher peak reduction at surface runoff, we obtained a $7.9 \%$ reduction in water depth height (Figure 14). 


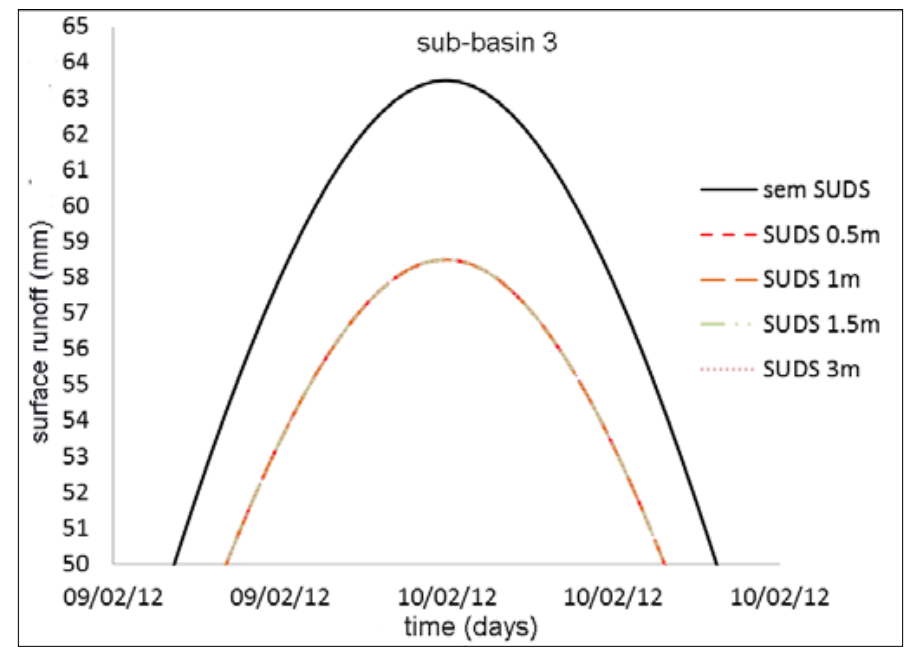

Figure 14 | Details of the graph with the peak runoff in sub-basin 3 with the permeable pavement structures and infiltration trench.

Source: Montagna (2019)

We identified that, from flow representations for this hydrological process, Suds structures depth does not result in substantial variations between them. The output data for this information are on daily basis, which allowed verifying the effects after 24 hours, and in small watersheds, the response time is shorter.

We highlight that the sub-basin $3\left(3.36 \mathrm{~km}^{2}\right)$, the second sub-basin with a higher proportion of Suds application area in the simulation, can be observed in Figure 15. It shows a sub-basin with the highest demographic density in the lower stretch of the Velha River basin. This indicates the benefit of a greater number of people with this proposal of Suds integration. We notice in this section a $10 \mathrm{~m}$ flood level, and the frequency in the occurrence of flooding events caused by intense rains of the last years in this same area.

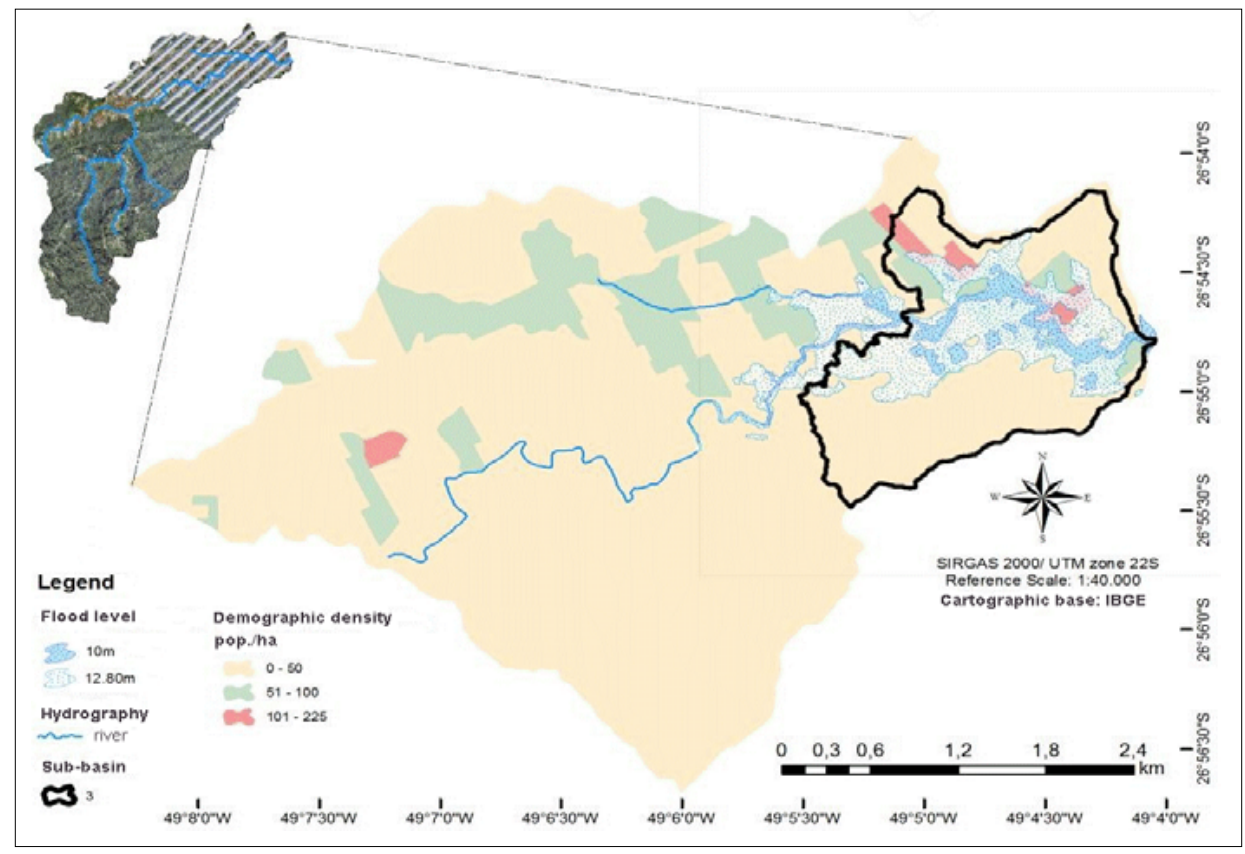

Figure 15 | Details of the graph with the peak runoff in sub-basin 3 with the permeable pavement structures and infiltration trench. 
In this sub-basin, we obtained a reduction of $7.9 \%$ in water depth for an event. This is equivalent to a reduction of $0.5 \mathrm{~cm}$ for the entire area of the sub-basin 3 for a $24 \mathrm{~h}$ period. The ideal is to check the values for shorter time intervals. However, this is a limitation, so far, for the option of output data daily.

Seo et al. (2017), also used the SWAT model, in this case, to quantify the flow and loads of pollutants under three land uses with different urban patterns with the combination of three Suds. The authors identified reductions in the flow of $29 \%$. However, the Suds area considered is $21 \%$ of the study area. It is noted that the area of application of Suds is significantly higher than that considered in this research, which covers $1.22 \%$ of the area $\left(54.05 \mathrm{~km}^{2}\right)$. Other studies that used SWAT to model Suds aim to evaluate the quality of water flow, sediment loads, nutrients, and contaminants (BRACMORT et al, 2006; KAINI; ARTITA; NICKLOW, 2012).

Several other studies have evaluated the impact of Suds on hydrological processes, however, they used other simulation models. Zanandrea (2016), through the Storm Water Management Model (SWMM), obtained reductions of $14 \%$ inflows with the application of Suds in $7.4 \%$ of the hydrographic basin under study. SILVA (2019), corroborates the benefits of the joint use of Suds techniques, obtaining a reduction of up to $36.37 \%$ of the volume in runoff simulation in urban areas. Nunes (2018) also evaluates techniques combination, with the implementation of green roofs and permeable pavements, in $50 \%$ of the total basin area, which generated a reduction of $10.9 \%$ in runoff volume.

Exploring the distribution of Suds in the hydrographic basin, Zellner et al (2016) presented, in one of the simulated layouts, the adaptation of the curb of the road to green infrastructure, identifying that they are more effective in reducing floods for all precipitation simulated than for other grouped layouts. They point out that even with only $5 \%$ of the area covered with Suds techniques adopted as green infrastructure, they still notice improvements through the Landscape Green Infrastructure Design (L-GrID) model.

In any case, given the characteristics of the study area, even with a low area of simulated application concerning the contribution area, positive results were obtained, assuming its contribution to accessibility, facilitating walking, and not pooling water in precipitation events. Thus, hydrological modelling and the application of Suds distributed throughout the watershed, link disaster risk management with drainage and urban mobility. With these tools they can encourage the use of sustainable techniques to obtain fewer impacts of the built areas on the hydrological processes, in addition to improving urban mobility, accessibility, as well as other environmental gains such as the infiltration of water in the groundwater, recharging groundwater and reducing heat islands.

\subsection{PERFORMANCE OF THE PERMEABLE FLOOR AND INFILTRATION TRACK}

The SWAT allows us to evaluate permeable pavement and infiltration trench structures in isolation through HRUs assessment. One of the criteria for HRUs creation is land use. In this case, the permeable pavement and infiltration trench are different uses and generate the delimitation of HRU by defining techniques in land use maps.

The SQUEM parameter (flow contribution) from HRU, permit the observation of contribution variation of the surface flow in these elements. In Figure 16, the flows generated without the Suds structures are observed and after application of a permeable pavement HRU and an infiltration trench HRU, both with the same area. 


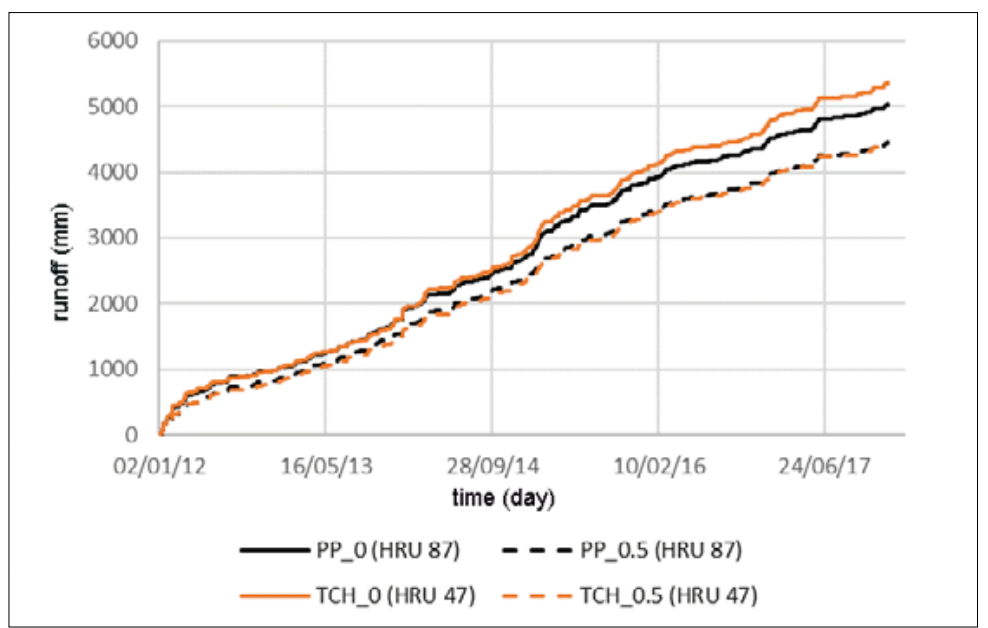

Figure 16 | Runoff in a permeable pavement HRU and an infiltration trench HRU for the simulated period.

Source: Montagna (2019).

HRU with a permeable pavement of an area equal to $0.005 \mathrm{~km}^{2}$ showed a reduction of $11.5 \%$ in the height of runoff. The HRU with an infiltration trench with an area equal to $0.005 \mathrm{~km}^{2}$ showed a $17 \%$ reduction in the height of the runoff. We can see that in these structures with the same coverage area, the infiltration trench showed the best flow reduction result, this can be justified by the fact that the permeable concrete coating has a lower hydraulic conductivity concerning the surface of the trenches. No similar approaches were identified in the literature, with individual analysis by $\mathrm{HRU}$, which according to the approached methodology represents the Suds technique.

Seo et al. (2017) highlight that despite the significant contribution of sustainable practices in most cases, a large amount of runoff can still be generated by heavy rainfall due to limitations in capacity and land use area. Several studies on the impacts of Suds on runoff show the results with combinations of techniques (ZELLNER et al, 2016; DU et al, 2016; SEO et al, 2017). Therefore, observing the impacts of these simulated structures it is noticeable that the combination and distribution of these structures in the hydrographic basin will present better results. Du et al. (2016) investigated the impact of landscape patterns on peak runoff and suggests that larger, less fragmented, and more connected landscape patterns are more likely to mitigate the average annual runoff peak.

\section{FINAL CONSIDERATIONS}

The elements that favour mobility are distributed over the entire length of urban areas. We highlight that sidewalks areas, cycle paths and paved areas of parks in the lower stretch of the Velha River basin, with the integration of these elements of permeable pavement and infiltration trench, showed positive results for the damping of the peak flow in the exutory the basin. This benefits the downstream stretches and the reduction of water depth in the surface runoff.

Replacing conventional structures with Suds (permeable pavement and infiltration trench), our study of hydrological simulation shows the impacts on the studied hydrographic basin water flow. In one event, there was a maximum reduction of $7.9 \%$ in the runoff of water depth. The contribution area (sub-basin) consisted of 10 to $11 \%$ with the Suds. There is a positive result with the impact of Suds on hydrological processes, corroborating the suggested hypothesis. 


\section{ACKNOWLEDGEMENTS}

This work was carried out with the support of the Coordination for the Improvement of Higher Education Personnel - Brazil (CAPES) and CNPq (process 309980 / 2017-8).

\section{REFERENCES}

AGÊNCIA NACIONAL DE ÁGUAS. Séries históricas. Disponível em: <http://www.snirh.gov.br/hidroweb>. Acesso em: 10 fev. 2018.

ARNOLD, J. G. et al. SWAT: model use calibration and validation. Transactions of Asabe, v. 55, n. 4, p. 1494-1508, 2012.

ASSOCIAÇÃO BRASILEIRA DE NORMAS TÉCNICAS. NBR 16416. Pavimentos permeáveis de concreto: requisitos e procedimentos. Rio de Janeiro, 2015. 25p.

BAPTISTA, M.; NASCIMENTO, N.; BARRAUD, S. Técnicas Compensatórias em Drenagem Urbana. 2. ed. Porto Alegre: $A B R H, 2011,318 p$.

BRACMORT, K. S. et al. Modeling Long-Term Water Quality Impact of Structural BMPS. Transactions of the Asabe, [s.l.], v. 49, n. 2, p. 367-374, 2006. American Society of Agricultural and Biological Engineers (Asabe).

CORREA, R.; CUNHA, K. B.; BOARETO, R. A bicicleta e as cidades: como inserir a bicicleta na política de mobilidade urbana. 2. ed. São Paulo: Instituto de Energia e Meio Ambiente, 2010. 86 p. Disponível em: <http://www. solucoesparacidades.com.br/wp- content/uploads/2010/01/02 - BRASIL_A bicicleta e as cidades_IEMA.pdf>. Acesso em: 10 mar. 2018.

DU, S. et al. Quantifying the multilevel effects of landscape composition and configuration on land surface temperature. Remote Sensing of Environment, [s.I.], v. 178, p. 84-92, jun. 2016. Elsevier BV. http://dx.doi. org/10.1016/j.rse.2016.02.063.

GREEN, W. H.; AMPT, G. A. Studies on soil physics-1. The flow of air and water through soils. Journal of Agricultural Science, Cambridge, v. 4, n. 1, p. 1-24, 1911.

KAINI, P.; ARTITA, K.; NICKLOW, J. W. Optimizing Structural Best Management Practices Using Swat and Genetic Algorithm to Improve Water Quality Goals. Water Resources Management, [s.I.], v. 26, n. 7, p. 1827-1845, 4 fev. 2012. Springer Science and Business Media LLC.

KNAESEL, K. M. Avaliação do Desempenho do Modelo Hidrológico Swat na Simulação da Qualidade da Água do Sistema de Drenagem Superficial na Bacia Hidrográfica do Rio Itajaí-Açu, gerando Cenários de Gestão de Recursos Hídricos. 2019. Dissertação (Mestrado em Engenharia Ambiental) - Fundação Universidade Regional de Blumenau, Blumenau, 2019.

LIU, J. et al. Seasonal Manure Application Timing and Storage Effects on Field - and Watershed - Level Phosphorus Losses. Journal of Environment Quality, [s.I.], v. 46, n. 6, p.1403-1412, 2017. Disponível em: <https://www.ncbi. nlm.nih.gov/pubmed/29293863>. Acesso em: 10 jul. 2018.

MONTAGNA, T.; VIEIRA, R. Infraestrutura de mobilidade urbana e sua articulação com a drenagem sustentável. Confins, [s.I.], n. 43, p.1-18, 9 dez. 2019. OpenEdition. http://dx.doi.org/10.4000/confins.24654. Disponível em: <https://journals.openedition.org/confins/24654>. Acesso em: 09 dez. 2019.

MONTAGNA, T. Pavimento permeável e trincheira de infiltração em espaços públicos que apoiam a mobilidade não motorizada como parte da gestão das águas pluviais em áreas urbanas. 2019. 136 f. Dissertação (Mestrado) - Curso de Engenharia Ambiental, Fundação Universidade Regional de Blumenau, Blumenau, 2019.

NUNES, A. A. Tendências em eventos extremos de precipitação na região metropolitana de Belo Horizonte: detecção, impactos e adaptabilidade. Tese (Doutorado) - Faculdade de Engenharia, Programa de Pós-graduação em Saneamento, Meio Ambiente e Recursos Hídricos da UFMG, Belo Horizonte. 2018. 
PAPAFOTIOU, E.; KATSIFARAKIS, K. I. Ecological Rainwater Management in Urban Areas. Preliminary Considerations for the City of Corinth, Greece. Agriculture and Agricultural Science Procedia, [s.I.], v. 4, p. 383-391, 2015.

PARAIZO, L. Temporal alaga ruas em Blumenau e região e deixa Defesa Civil em alerta máximo. NSC Santa, Blumenau, 16 jan. 2018. Disponível em: <http://jornaldesantacatarina.clicrbs.com.br/sc/geral/noticia/2018/01/ temporal-alaga-ruas-em- blumenau-e-regiao-e-deixa-defesa-civil-em-alerta-maximo-10120149.html>. Acesso em: 15 fev. 2018.

PORTO, R. L. L. Escoamento Superficial Direto. In: TUCCI, C. E. M.; PORTO, R. La L.; BARROS, M. T. M. de. (Org.). Drenagem Urbana. SÃO PAULO: ABRH, 1995, v. V, p. 107-165.

PORTO, R. L. L. et al. Fundamentos para a Gestão de Águas. São Paulo - SP: CDG Casa de Soluções e Editora, 2012. v. 1000. 229p.

SANTOS, Á. R. Cidades e geologia: discussão técnica e proposição de projetos de lei de grande interesse para as populações urbanas. São Paulo: Rudder, 2009. 136 p.

SCHULT, S. I. M.; PINHEIRO, A. Ocupação e Controle das áreas urbanas inundáveis. In: FRANK, B.; PINHEIRO, A. (Org.). Enchentes na bacia do Itajaí: 20 anos de experiências. Blumenau: Editora da Furb, 2003, v. 1, p. 173-190.

SEO, M. et al. Evaluating the Impact of Low Impact Development (LID) Practices on Water Quantity and Quality under Different Development Designs Using Swat. Water, [s.I.], v. 9, n. 3, p. 193-210, mar. 2017.

SILVA, J. F. F. Alternativas para controle de alagamentos urbanos utilizando telhados verdes e pavimentos permeáveis em um bairro da cidade do Recife. 2019. 115 f. Dissertação (Mestrado em Engenharia Civil e Ambiental) - Universidade Federal de Pernambuco, Caruaru, 2019.

TOMINAGA, E. N. S. Urbanização e Cheias: medidas de controle na fonte. 2013. 137 f. Dissertação (Mestrado em Engenharia Hidráulica e Ambiental) - Escola Politécnica da Universidade de São Paulo, São Paulo, 2013.

VENZON, P. T. Efeitos das mudanças de discretização espacial no comportamento da vazão em sub-bacias pertencentes à bacia hidrográfica do Itajaí. 2018. Dissertação (Mestrado em Engenharia Ambiental) - Fundação Universidade Regional de Blumenau, Blumenau, 2019.

WAGENER, T.; WHEATER, H.; GUPTA, H. V. Rainfall-Runoff Modeling in Gauged and Ungauged Catchments. London: Imperial College. 306 p. 2004. Disponível em: <www.worldscientific.com/worldscibooks/10.1142/ p335>. Acesso em: 10 jun. 2018.

WANG, Y. A Diagnostic Decision Support System for Selecting Best Management Practices in Urban/Suburban Watersheds. 2015. 312 f. Tese (Doutorado) - Curso de Filosofia, Departamento de Engenharia Civil, Universidade de Maryland, College Park, 2015.

ZANANDREA, F. Avaliação de Técnicas de Baixo Impacto no Controle de Impactos Hidrológicos em uma Bacia Urbana em Consolidação. 2016. 93 f. Dissertação (Mestrado em Recursos Hídricos e Saneamento Ambiental) Universidade Federal do Rio Grande do Sul, Porto Alegre, 2016.

ZELLNER, M. et al. Exploring the effects of green infrastructure placement on neighborhood-level flooding via spatially explicit simulations. Computers, Environment and Urban Systems, [s.I.], v. 59, p. 116-128, set. 2016. Elsevier BV. http://dx.doi.org/10.1016/j.compenvurbsys. 2016.04.008. 